\title{
A CRITICAL EXAMINATION OF MIGRATION AND GLOBALIZATION: IMPLICATION FOR DEVELOPMENT IN AFRICA
}

\author{
Martin F. Asiegbu* \& J. Chidozie Chukwuokolo* \\ http://dx.doi.org/10.4314/og.v16i1.1
}

\begin{abstract}
This paper argues that there is a relationship between globalization and migration in the sense that increased reduction in global borders enhances migration. Migration on its own has raised some human right concerns. This is because as communities are growing closer, trade, politics, culture, technology e.t.c., raise some conflicts of ideology. This paper surmises that unless there is a way of humanizing the unevenness in the mercantile relationships that exists between Western nations and their Third world counterpart, the world will not benefit from these interactions as we have seen in the 21 st Century slavery witnessed in Libya where humans were auctioned like goats. In the ideological pedestal, the challenges posed by Islamic migrants have become very mendacious. However, the aim of this paper is to examine globalization and migration and its implication for development in Africa. The movement of skilled and / or wealthy Africans is generally viewed negatively. For instance, there is long-standing concern on the African continent with the impact of the 'brain drain' of African professionals. Nevertheless, slowly and very few places, is understanding arising of the potentially positive role that migration itself can play in development or of the possibilities for 'mobilization' of the African Diaspora in the fight against poverty.
\end{abstract}

Keywords: Migration, globalization, development and ideology

\section{Introduction}

Globalization, migration and human right have come to be cardinal themes and challenges dominating international discourse. Matters concerning these themes are at the apex of most of the conflicts in the social, political and economic realms in this contemporary era. Globalization is identified by the general increase in international 
flows of goods, input factors, technology and financial assets, with all these components growing consistently more rapidly than output. In line with this definition, there are two episodes of globalization in modern economic history: the first happened in the late nineteenth and early twentieth century while the second is currently ongoing and commenced roughly thirty-two year ago. According to Hillel Rapoport in both episodes, "the growth rate of international trade largely exceeded the rate of output growth, leading for example to a tripling of the world trade/GDP ratio in just a few decades, between 1960 and 2005." It has to be noted that there is a difference between these two episodes of globalization. The first is termed 'the age of mass migration' while the current era is a period of globalization for everything except people.

Migration is an old age phenomenon in human history. This phenomenon has become more extensive and intensive under the impact of contemporary globalization. Migration within countries and across borders can be seen as an integral part of labour markets and livelihoods across much of the continent for at least the last century. According to Southern African Migration Project, "migration represents an important livelihood strategy for poor households seeking to diversify their sources of income, but is also characteristic of the better off, and indeed of many African elites." Migration takes place for various reasons. Recent developments in global society have virtually made human displacement and movement across frontiers inevitable. The increasingly severe breakdowns in the economic, political, social and environmental realms continue to make it more difficult for people particularly in the world's economic peripheries to survive and remain in their traditional communities and countries. Thus, migration is often seen as a strategy to escape from poverty.

A lot of factors combined to trigger Africans migration and Africa being considered the world's top refugee producing region. Among those factors include several violent internal conflicts and civil wars that plagued many African states particularly in the period since the end of the cold war. Apart from war, demographic mobility and human displacement have led to other factors involving economic crisis confronting African states. According to Aderemi 
Asiegbu \& Chukwuokolo: A Critical Examination of migration ...

the following factors among others condition the migration of Africans:

The emergence of autocratic and oppressive regimes and the accompanying political repression; the brain drain syndrome and the search for economic and social mobility by professionals in various spheres; the search for educational and training opportunities by many young people consequent upon the destruction of educational systems in many African states, etc ${ }^{3}$.

Currently, various aspects of globalization contribute to increase migration. Travelling is easier than before. Television images, reaching even far away villages of poor countries, increased awareness about the enormous differences in life conditions around the globe. They feed dreams of a better life. "The mesmerizing environment of the rich world is often perceived as a sort of paradise on earth that everybody can enjoy by simply being there."4 The easy worldwide technological connections facilitate international movements of human beings. No wonder, Ozden said that "the share of people living in a country which is different from their country of birth has remained remarkably stable over the last four decades, around three percent of the world population." "This is to say, the number of migrants worldwide has increased more or less at the same pace as the world population since World War II. Thus, "the world appears much less open to migration than a century ago, at a time when international migration was essentially free and the share of migrants in the world population was two to three times higher than what it is today."6

However, the aim of this paper is to examine globalization and migration and its implication for development in Africa. The movement of skilled and/or wealthy Africans is generally viewed negatively. For instance, there is long-standing concern on the African continent with the impact of the 'brain drain' of African professionals. Nevertheless, slowly and very few places, is understanding arising of the potentially positive role that migration itself can play in development or of the possibilities for 'mobilization' of the African Diaspora in the fight against poverty. 
Moreover, public policy remains a long way from building effectively on such understanding. At the end of our exposition of the two concepts, their implication for development in Africa will be x-rayed.

\section{The Concept of Globalization and Migration}

Globalization is associated with an increasingly dominant process of economic change; whereby economic transactions take place regardless of national jurisdictions. Some argue that globalization represents "the construction of a liberal world economic order and brings with it demonstrable benefits in the form not only of free market economies but also liberal forms of representative democracy."7 Globalization entails that the outcomes of economic decisions are felt ever more quickly by increasing numbers of those who do not take the decisions and who indeed may be thousands of miles from the site of decision-making. Countries embracing the cause of globalization are themselves less enthusiastic about some of its impacts, increasingly finding that their ability to exercise political and economic control within their boundaries is compromised by footloose economic actors. These actors move capital to labour, free from national controls, as they have done for a century or more, but nowadays also increasingly view the international migration of labour to capital as a good.

The acceleration of the phenomenon of human displacement and demographic mobility in recent years cannot be separated from the phenomenon of globalization. Globalization has come to explain the trends and initiatives targeted at reshaping national and international economic life. Globalization initiatives aim at the global integration of economic activity including production, marketing and consumption of goods and services. "A principal feature of the phenomenon is the steady elimination of restrictions on the free movement across borders of capital, goods, resources, technology, and services but not of labour." 8

Migration continues to increase in scope, complexity and impact. Demographic transaction, economic growth and recent financial crisis are restructuring the face of migration. At the heart of this phenomenon are human beings in search of decent work and a better or safer life. Across the globe, millions are able to move, live 
Asiegbu \& Chukwuokolo: A Critical Examination of migration ...

and work in safety and dignity. Yet others are compelled to move owing to poverty, violence and conflict, or environmental changes, and many face exploitation, abuse and other human rights violations along the way. Changes in global production coupled with the globalization of labour markets continue to drive the international movement of labour. In some nations, population ageing adds to labour demands that cannot be met locally. For growing numbers of young people, migration represents the only viable strategy to find gainful employment.

Innovation in transportation and technology allow people to migrate with greater frequency over greater distances. With mobility becoming an affordable option for most of the world's citizens, circular migration, return migration and short-term mobility by individuals increasingly compliment long-term settlement by families. The turnout is a more fluid, diverse and nuanced reality, where traditional categorizations and simple dichotomies are increasingly outdated. Despite all these, globalization has not proved to be a positive development for all people not least those in Africa. One consequence of globalization for all people around the developing world has been growing unemployment or underemployment, decrease in the salary of the employed, decrease in education, health care and increasing marginalization and exclusion. These elements of globalization in conjunction with the consequences of economic collapse lead to the generation of the phenomenon of demographic mobility. Increase in cost of food items and generate inflation together with unemployment rates pushes more and more people with no option but to depart their native land in search of food and work and consequently to the rate of migration. This is why Harris argued that "increased migration is inevitable in an integrating world economy that is increasingly characterized by widening inequalities between the rich and poor nations." 9 To buttress this, Lenin contended that migration is a function of the laws of uneven development caused by capitalization and that the "high level of technological development attained by industrialized countries confer on their people and workers in particular, a high level of per capita income, which attracts migrants (labour) from less developed countries." 10 These theories prove the movement of 
several developing nations especially Africa which is our concern in this paper.

However, more attention has recently been devoted to migration due to 'development policies' and the involvement of 'northern' countries in contributing to poverty alleviation in the South. This is sequel to the discovery that enormous sums are transferred worldwide by international migrants to the 'home front' and that these remittances can contribute to poverty alleviation. World Bank estimated that "a sum of no less than 372 billion dollars was involved in 2011."11 The amount is larger than the official development aid. It is understandable therefore that policy makers started to see in these transfers an additional financing source for development.

Furthermore, can international migration create a sustainable development? In answering this question, there are two opposing views. Some emphasise the potential benefits of migration. They argue that it impacts positively upon all stakeholders, evidenced by the fact that sending sites and the migrants themselves benefit because migrants get jobs, develop their skills, earn some money and remit part of it to their places of origin while destination sites benefit from the skills and labour they get from migrants.

Migration is viewed as a positive factor, because it leads to equilibrium on the labour market and because international labour migration is expected to contribute to the banishment of inequality and to lead to a better sharing of the advantages of globalization. ${ }^{12}$

On the other hand, some argue on the problematical aspects of migration and the imposing dangers. For them international migration can lead to conflicts in the receiving countries and at the same time create negative consequences for the countries of origin (the loss of man and woman power and brain drain). This is because often the best and the brightest able-bodied people leave first. In this case, they only return back to their home country when they have aged. "Returning migrants are likely to be the old, sick and unsuccessful and skills brought back are unlikely to be of much 
Asiegbu \& Chukwuokolo: A Critical Examination of migration ...

help."13 This has unavoidable adverse effects in the country of origin. Moreover, despite the opposing opinions, there is rising consensus emerging currently, that although international migration does not automatically lead to beneficial effects, it can contribute to development and poverty reduction, provided an appropriate and consistent policy is pursued. Should migration be allowed unchecked; If so what are its implications for development in Africa?

\section{The Implication of Globalization and Migration for Development in Africa}

The economic benefits of globalization clearly are unevenly distributed. This is because rarely does global economy touch many parts of the world. Though exception can be given to places where they provide the source of cheap labour; Globalization in reality opens up new opportunities for growth for the biggest economic players that are increasingly dominating economic activity, free from political accountability. According to Garry:

The world's 100 largest economies now include 50 giant corporations, none of which are controlled indigenously within Africa. The five largest global companies have combined sales greater than the total incomes of the world's 46 poorest nations, the majority of which are also African. ${ }^{14}$

The truth behind corporate globalization is evident in Milton's statement which says that "such corporations cannot be ethical; their only responsibility is to make profits." 15

Historically, in organized diasporic communities, there is evidence that the emergent migrant networks impacted on developments in their home states politically, socially and economically, as well as in security terms. But, apart from high profile political activities and those with security implications including attempts to subvert and replace autocratic regimes in their home states, the more routine activities of diasporic communities are also worthy of attention. For instance, many migrants had departed their homelands in search of the proverbial greener economic 
pastures. The aspirations and expectations of many of their kith and kin inevitably became focused on diaspora-based relations and friends. This has resulted to some families or parents selling their properties like land, jewellery and even borrowing money just to send their child abroad. They do this hoping that he/she will go there, make money and bring back home to better their standard of living. In the harsh economic environment prevailing in several African states, personal survival many times hinged on what migrant relations were able to send back home either regularly, occasionally, or at agreed intervals. This is the root of what has since become known as the 'remittance economy', that is, financial remittance from diaspora relatives that constituted significant sources of income for several families in home states, otherwise known as the informal money transfer systems (IMTS).

Remittances augment the income of households and are often spent on basic subsistence needs, such as food, housing and clothing, and on durable goods. Remittances are also used to pay for health and education, directly improving human capital. Remittances that are spent or invested in countries of origin help generate income and employment. Remittances per se, however, are not sufficient to ensure investment and savings by remittance-receiving households. The financial environment in countries of origin must be hospitable to investment and migrants must be able to trust the government and institutions for affectivity.

According to several estimates; "the amount that flow through these informal channels (IMTS) range from one hundred billion dollars every year." 16 Funds from these sources have been crucial to the economy of many African states particularly in Southern Africa where migrant workers employed in South Africa have contributed significantly to the foreign exchange earnings of many of these states. In all, the economic dimensions of the activities of diaspora communities are significant.Migrants who have become successful entrepreneurs in their destination countries play important roles inflows of foreign direct investment (FDI). Diaspora communities can be both a direct source of FDI and effective intermediaries to channel FDI towards home countries.

More so, several countries have developed policies and programme to encourage diaspora populations to make greater financial 
Asiegbu \& Chukwuokolo: A Critical Examination of migration ...

investments in their homelands. Strategies include providing access to information regarding investment opportunities, facilitating connections with homeland business networks and investing in public infrastructure in support of FDI projects. Countries of origin also benefit from the ideas and behaviours of returning migrants. Social remittances can have an impact in creating a more conducive environment for development initiatives at home.

In reference to Africa, a distinction can be made between North Africa, which in the past provided large numbers of migrant workers for Europe, and sub-Saharan Africa, which has recently started to generate increased migration streams in various directions, including Europe, the US and the Middle East. In addition to reflecting traditional systems of 'transhumance', colonial ties and economic relations are important factors in explaining migration patterns within and from the region. Of those African migrants who go 'overseas', a lot go the former colonial powers such as France or the UK, although many others are now moving to other European countries such as Italy or Spain, North America and Middle East.North Africa especially Morocco, is better able to benefit from migration, due to the diasporic character of the migration flow predominantly directed towards Europe in combination with the presence of historic relations, rooted in the guest worker programs of the 1960s and 1970s. More so, "the Moroccan government recognizes the value of their diaspora and as such invested heavily in diaspora engagement policies." 17

In Sub-Sahara Africa, the conditions to benefit are less favourable. In comparison with Latin America and Asia, migration in sub-Sahara Africa is relatively unstable. Africans are displaced due to armed conflicts, economic distress and environmental degradation, factors that in many cases are interrelated. Throughout Africa, the problems resulting from the brain drain are enormous, in particular the loss of doctors, nurses, teachers and entrepreneurs who have left in search of opportunities or better working conditions elsewhere. Compared with Latin America and Asia, the volume of remittances sent back to Africa is relatively small. More than in other continent, "migration research in Africa is hindered by the lack of reliable data, and migration policies are relatively less developed." 18 
In South-North migration, some African countries participate in co-development programs: programs implemented by organizations in European destination countries aimed at linking immigrants and their organizations to development processes in the region of origin, often in the context of development cooperation. Development funds are for stimulating development 'at home', while aiming at stimulating return migration and bringing migration under control. An example of this includes "Spanish programs targeting Morocco, Gambia and Senegal, and French programs directed towards Mali and Senegal, amongst others." 19 The impact of migration on poverty reduction and development has only been studied in recent years. However, as much as migrant remittances are a useful and important factor, are not a magic bullet and are not a substitute to adequate national and international development policies. Remittances need sound domestic economic policies to be used even more effectively.

\section{Conclusion}

The 'migration' component of globalization has long been seen either as a safety net (allowing to export one's demographic surplus and receive insurance income from remittance) or as a threat for developing countries to integrate further into the world economy. Specifically, in light of recent empirical evidence, the role of migration and diaspora networks must be considered as a potentially significant generator of brain drain. Moreover, even though in migration debates and theories much attention is given to "the" potential development benefits of international migration, our analysis shows that there is no levelled playing field. This is also true because the majority of sending countries have as yet no clear view on how to deal with the moving ins and moving outs.

However, development in recent years reveals the emergence of new dimensions to the phenomenon of demographic mobility and involuntary migration. The lines of distinction between refugees and migrants have become substantially blurred. The various fallouts of globalization have also added to the complexities of the modern phase of international migration. According to Oraegbunam, 'facing the challenges of globalization demands an efficient, responsible and corruption-free leadership, and good 
Asiegbu \& Chukwuokolo: A Critical Examination of migration ...

governance. This is because, corruption and governmental insensitivity by which leaders have placed their retention of power and personal enrichment ahead of the interest of the countries they lead constitute one important obstacle on the way to African development. Properly enacted legal framework, adherence to the rule of law, respect for human rights, accountability and transparency guarantee a genuine democratic space and enabling socio-economic environment necessary for human development' ${ }^{20}$

Ironically, Africa's perceived marginalization in the international system given the development in the global economy has contributed to the 'globalization' of Africa and Africans as the people have been forced to respect Lenin's thesis that uneven development is a trigger for migration and that the technological attainments of the developed countries is an attraction for migrant labour to move to such economies. But internal developments have also encouraged and facilitated the emigration of Africans to other lands. Migrant networks pose various challenges to both host and home countries. According to Aderemi:

Recent developments confirm that a number of African countries are beginning to recognize the widespread significance of the phenomenon. For example, the Nigeria government of President OlusegunObasanjo appointed a Special Assistant to the president on Nigerians in the Diaspora. It is expected that this could assist the evolution of rational national policies to deal with this phenomenon in the years to come. ${ }^{21}$

Migration is a phenomenon as complex as it is unstoppable. Managing it adequately will require hard work, commitment, research, reflection, understanding and, most of all political courage. Global cultural transformations will be necessary. Member states should seek to improve public understanding of migrant contributions to home and host societies and address misconceptions of migration. Such efforts could be reinforced through national action plans developed in collaboration with the private sector, the media and organizations representing migrants, employers and 
Ogirisi: a new journal of African studies vol. 162020

workers. The probability of social security benefits for migrants should be improved through bilateral or multilateral agreements.

* Rev. Fr. Martin. F. Asiegbu, PhD

Senior Lecturer, Department of Philosophy,

University of Nigeria, Nsukka

*J. Chidozie Chukwuokolo, PhD

Senior Lecturer, Department of Philosophy and Religion, Ebonyi State University, Abakaliki 
Asiegbu \& Chukwuokolo: A Critical Examination of migration ...

\section{References}

${ }^{1}$ Hillel Rapoport, "Migration and Globalization: What's in it for Developing Countries?",Discussion Paper Series, IZA, (July, 2016), 2.

${ }^{2}$ Richard Black, J. Crush \& et al, "Migration, Poverty \& Development in Africa: An overview, African Migration and Development Series No. 1, (SAMP, 2006), 1.

${ }^{3}$ Aderemi Ajibewa, "Globalization, Migration and the New African Diaspora: Towards a Framework of Understanding", Sussex Centre for Migration Research (March, 2003), 1-9.

${ }^{4}$ Maurizio Muru, "Globalization, Migration and Brain Drain: A Reality Check", Health Policy and Development, Vol. 6, No. 3 (Dec., 2008), 153-163.

${ }^{5}$ C. Ozden and Persons C. R. \& et al, Where on Earth is Everybody? The Evolution of Global Bilateral Migration 1960 - 2000, World Bank Economic Review 25 (2011), 12-56.

${ }^{6}$ Livi-Bacci M., A Short History of Migration (Wiley, 2012).

${ }^{7} \mathrm{G}$. Venters, "Globalization: Contested Meanings and Alternative Futures", Concept 12(1) (2002), 5-10.

${ }^{8}$ Patrick A. Taran, "Migration, Globalization and Human Rights: New Challenges for Africa" African Commission on Human and Peoples Rights/ ICJ Workshop, Rwanda (Nov., 1999). (http://www.migrantwatch.org/pages/articles/workshops/ICJ 99).

${ }^{9}$ Nigel Harris,The New Untouchables: Immigration and the New World Workers (London: I. B. Tauris, 1997), 85.

${ }^{10}$ V.I. Lenin, Imperialism, The Highest Stage of Capitalism (New York: International Publisher, 1939).

${ }^{11}$ World Bank, Migration and Remittance FactBook 2011, $2^{\text {nd }}$ ed., (Washington DC USA: The World Bank, 2011).

${ }^{12}$ Annelies Zoomers and G. Nijenhuis, "Does Migration lead to Deveoplment? Or is it Contributing to a Global Divide?" Open Access Societies Vol. 2 (2012), 122-138.

${ }^{13}$ de Haan A., Migration in the Development Studies Literature: Has it come out of Marginality? UNU - WIDER Jubilee Conference, Helsinki, Finland, 17 - 18 June, 2005. 
Ogirisi: a new journal of African studies vol. 162020

${ }^{14}$ Garry Craig, "Globalization, Migration and Social Development", The African e-Journal Project. (http://digital.lib.msu.edu/projects/africanjournals/).

${ }^{15}$ Milton Friedman, Capitalism and Freedom (Chicago: University of Chicago Press, 1962), 161.

${ }^{16}$ Buencamino L. and S. Gorbunov, "Opportunities and Challenges for Development Finance", in Aderemi A., "Globalization, Migration and the New African Diaspora: Towards a Framework of Understanding", Sussex Centre for Migration Research (March, 2003), 1-9.

${ }^{17}$ Iskander N., Creative State: Forty Years of Migration and Development Policy in Morocco and Mexico (USA: Cornell University Press, 2010).

${ }^{18}$ Zoomers A., G. Rivera and et al, "Migration in a Globalizing World: Knowledge, Migration and Development. inKnowledge on the Move: Emerging Agendas for Development-Oriented Research,Molenaar H.(Netherlands: International Development Publications, 2009), 89-122.

${ }^{19}$ Nijebhuis G. and A. Broekhuis, "Institutionalizing International Migrants' Activities, the Impact of Co-development Programme", International Development Planning Review 32 (2010), 246-265.

${ }^{20}$ Ikenga K.E. Oraegbunam, 'Africa in a Globalizing World: Problems, Prospects and Challenges', Philosophy and Praxis, vol. 2, 2006, pp. $30-46$.

${ }^{21}$ AderemiAjibewa, "Globalization, Migration and the New African Diaspora: Towards a Framework of Understanding", Sussex Centre for Migration Research (March, 2003), 1-9. 